\title{
Circle Hairs in a Patient with Multiple Myeloma
}

\section{Preeyachat Limtong (D) \\ Poonkiat Suchonwanit (D)}

Division of Dermatology, Department of Medicine, Faculty of Medicine,

Ramathibodi Hospital, Mahidol

University, Bangkok, Thailand
Correspondence: Poonkiat Suchonwanit Division of Dermatology, Department of Medicine, Faculty of Medicine,

Ramathibodi Hospital, Mahidol University,

270 Rama VI Road, Ratchathewi, Bangkok, 10400, Thailand

Tel +66-2-20I I I4I

Fax +66-2-20I-I2II ext 4

Email poonkiat@hotmail.com

\begin{abstract}
Circle hair is a rare body-hair disorder of unknown etiology, typically characterized by perfectly or nearly perfectly coiled hair located below the cornified layer of the skin. Its main histopathological features are dilated hair-follicle infundibula and entrapped hair shafts. After its first description in 1963, there have only been a small number of reported cases, and its pathophysiology remains unclear. Herein, we report a case of an 80-year-old woman with skin lesions and abnormal hairs on both legs. We also propose a possible mechanism of her circle hairs: it may have occurred as an effect of her acquired ichthyosis secondary to her underlying multiple myeloma. There is no specific treatment for circle hairs, and reassurance that it is a harmless condition is sufficient. We prescribed a topical humectant and keratolytic agent to moisten the skin and lessen the hair entrapment, which resulted in clinical improvement. As the pathogenesis of the disease is unknown, further studies are warranted.
\end{abstract}

Keywords: body hair disorder, hair diseases, hair follicle, ichthyosis, case report

\section{Introduction}

Circle hair is a rare body-hair disorder characterized by the presence of hair rolled in perfect or nearly perfect concentric circles under a thin layer of stratum corneum without accompanying follicular hyperkeratosis or signs of inflammation. ${ }^{1,2}$ The condition was first described by Adatto in $1963 .^{2}$ There are, to our knowledge, no reports of the association of circle hair with underlying dermatological or systemic diseases, and its pathomechanism remains unclear. ${ }^{1,3}$ We present a case of circle hair in an 80-year-old woman with multiple myeloma who had skin lesions and abnormal hairs on both legs.

\section{Case Presentation}

An 80-year-old, bedridden woman with multiple comorbidities (ie, multiple myeloma being managed with palliative therapy; thalassemia; syndrome of inappropriate antidiuretic hormone; hypertension; and dyslipidemia) visited our institution with a 3-month history of slowly progressive skin lesions and abnormal hairs on her lower extremities. Her caregivers noticed these cutaneous abnormalities after the diagnosis of multiple myeloma. Her relatives were not aware of any trauma that the patient had experienced to the affected areas, and no family members had the same skin lesions. At the time of her visit, the patient had been using lorazepam, oxycodone, morphine, folic acid, sodium chloride, vitamin B complex, and lactulose for more than 3 years.

Physical examination revealed multiple brown scales with adherent centers and detached, outward-turning edges, with multiple, overlying, small black dots on the 

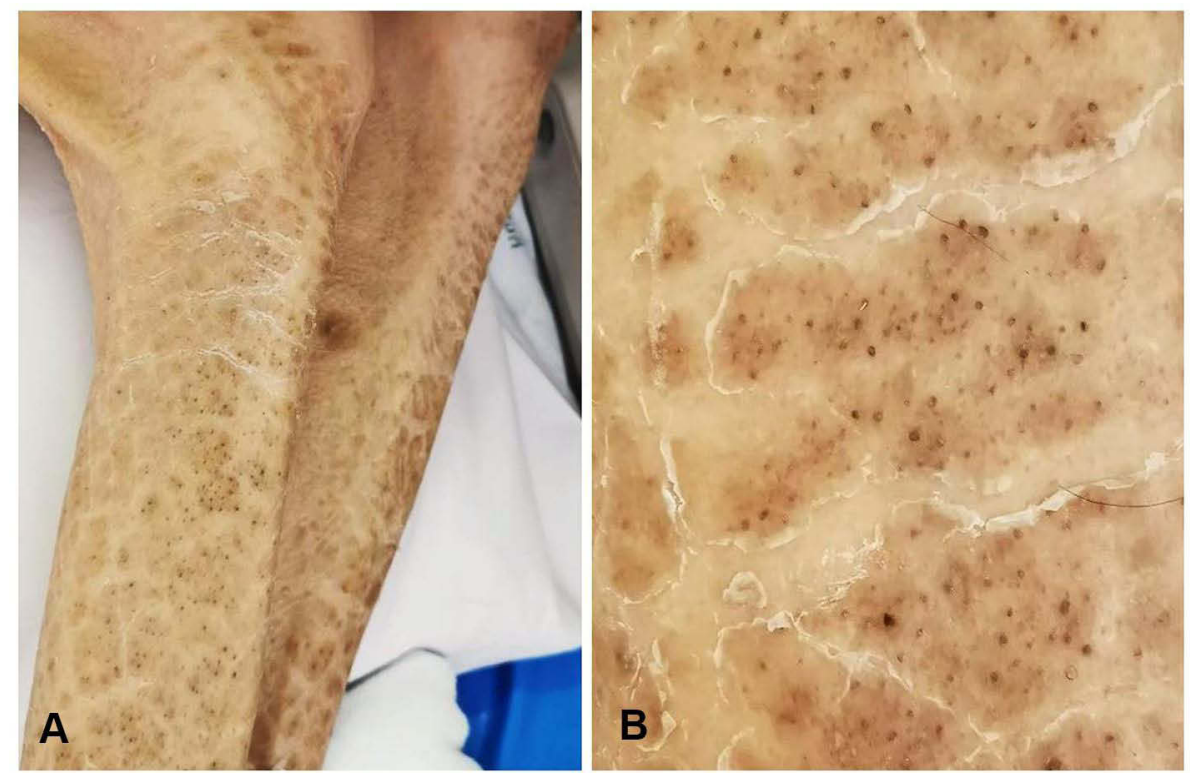

Figure I Dermatological examination: (A) multiple brown scales with adherent centers and detached, outward-turning edges, with multiple, overlying, small black dots on the extensor areas of both lower extremities; (B) close-up view showing abnormal hairs on the areas of skin abnormality.

extensor areas of both lower extremities, sparing the flexural areas, as well as abnormal hairs on the areas of skin abnormality (Figure 1). Dermoscopic examination revealed multiple dark hairs with a perfectly circular arrangement, located under a thin layer of skin (Figure 2). The patient's other systems were unremarkable. Histopathological examination revealed laminated hyperkeratosis with hypogranulosis, which was most compatible with ichthyosis. The specimen also contained a dilated hair follicle (Figure 3). Based on her clinical information and the dermoscopic and histopathological features, the patient was diagnosed with circle hair and acquired ichthyosis. The patient was treated with $10 \%$ urea cream, twice daily, and $10 \%$ lactic acid cream, once daily. The lesions had slightly improved by the 1-month follow-up visit.

\section{Discussion}

Circle hairs (or spiral hairs) are otherwise asymptomatic, dark hairs with a perfectly or nearly perfectly circular arrangement in the subcorneal layer of the skin, without
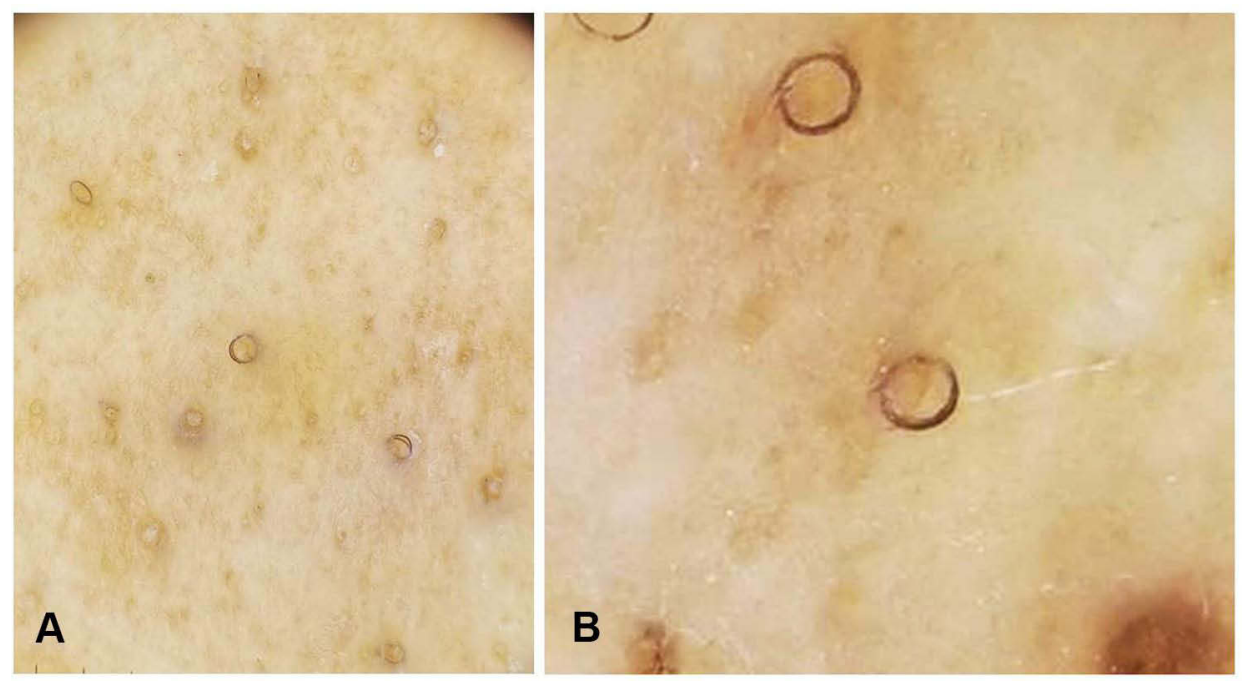

Figure 2 Dermoscopic examination: (A) multiple dark hairs with a perfectly circular arrangement, located under a thin layer of skin (original magnification x20); (B) closeup view of circle hairs (original magnification $\times 80$ ). 


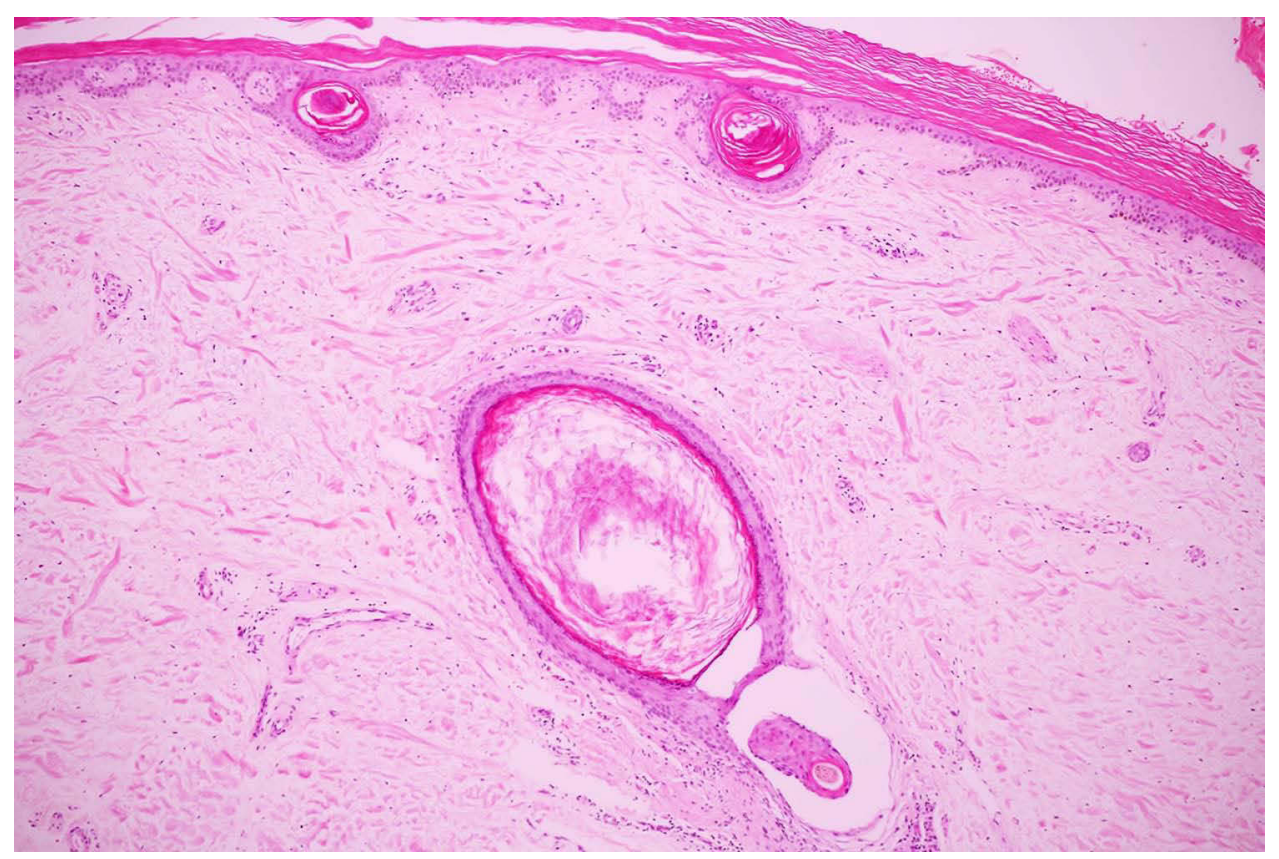

Figure 3 Histopathological examination: laminated hyperkeratosis with hypogranulosis and a dilated hair follicle.

any signs of inflammation. ${ }^{1,4,5}$ They are most commonly noted in very hairy, overweight, middle-aged men in the range of 55-74 years old and can be surrounded by normal hairs. ${ }^{1}$ The reported cases of circle hairs are scarce; however, this condition may be underdiagnosed owing to its asymptomatic nature. Common locations for circle hairs are the back, chest, abdomen, shoulders, thighs, and upper portions of the legs. ${ }^{1,4}$ They are easily extracted by superficial scraping with a lancet, upon which they exhibit the characteristic question-mark shape and a typical length of 2-2.5 cm. ${ }^{1}$

Dermoscopic examination of circle hairs reveals that their shafts are slightly smaller than those of normal hairs, and they coil into a distinctively circular configuration under the translucent stratum corneum. ${ }^{2}$ Microscopic inspection reveals a narrowing hair shaft that forms a ring, with dystrophic anagen hair bulbs and the absence of an inner root sheath. ${ }^{2}$ Typical histopathological findings include the presence of "river-bed," dilated hair-follicle infundibula with entrapped hair shafts. ${ }^{2}$ No follicular obstruction or perifollicular inflammation has been noted for this condition. ${ }^{4}$

The most important differential diagnosis of circle hairs are rolled hairs, which consist of symptomatic, irregularly twisted hair shafts that do not form a nearly perfectly circular arrangement and are located within hyperkeratotic papules, frequently present in the extensor regions of the extremities, shoulders, back, and buttocks. ${ }^{4,6}$ Rolled hairs are reportedly linked to follicular hyperkeratosis and inflammation. ${ }^{1,4}$ Many conditions are reportedly associated with rolled hairs, including palmoplantar keratoderma, keratosis pilaris, xerosis, and other dermatitis associated with chronic itching skin, as well as with the use of medications such as corticosteroids and cyclosporine. ${ }^{1,7-10}$ Other hair disorders that resemble circle hairs, which may be included in the differential diagnosis, include pigtail hairs, ${ }^{11-14}$ coiled hairs, ${ }^{12,14,15}$ and corkscrew hairs. ${ }^{12,16,17}$ Table 1 summarizes the clinical, dermoscopic, and histopathologic features of circle hair and its mimickers. The dermoscopic characteristics for our patient were compatible with circle hairs because of the hairs' perfectly coiled nature, despite the absence of the characteristic river-bed appearance upon histopathology.

The pathogenesis of circle hairs remains unknown, although there are two possible explanations. The first is that their thin diameter leads to an inability to penetrate the stratum corneum, resulting in their concentric circular growth. The other is that circle hairs are remnants of the mammalian undercoat. ${ }^{1}$ There are no reported associations between circle hairs and medications or underlying diseases. ${ }^{2,3}$ However, drugs that have the ability to promote hair growth, including corticosteroids, tacrolimus, and mycophenolate, may initiate this condition. ${ }^{3}$ 
Table I Clinical, Dermoscopic, and Histopathologic Features of Circle Hair and Its Mimickers

\begin{tabular}{|c|c|c|c|c|c|}
\hline & Circle Hair & Rolled Hair & Pigtail Hair & Coiled Hair & Corkscrew Hair \\
\hline Epidemiology & $\begin{array}{l}\text { - Overweight } \\
\text { - Middle-aged man }\end{array}$ & - & $\begin{array}{l}\text { Not specific, may be } \\
\text { found as a result of } \\
\text { rapid hair regrowth in } \\
\text { children }\end{array}$ & $\begin{array}{l}40 \% \text { in patients } \\
\text { with } \\
\text { trichotillomania } \\
\text { and very rarely } \\
(<1 \%) \text { in alopecia } \\
\text { areata and tinea } \\
\text { capitis }\end{array}$ & - \\
\hline $\begin{array}{l}\text { Clinical } \\
\text { morphology }\end{array}$ & $\begin{array}{l}\text { A perfectly } \\
\text { concentric hair } \\
\text { under a thin skin } \\
\text { layer dispersed } \\
\text { among surrounding } \\
\text { normal hairs }\end{array}$ & $\begin{array}{l}\text { An irregularly coiled hair } \\
\text { shaft with not perfectly } \\
\text { circular configuration into } \\
\text { a hyperkeratotic papule, } \\
\text { signs of inflammation, and } \\
\text { peripilar casts may be } \\
\text { present }\end{array}$ & $\begin{array}{l}\text { A short, regularly } \\
\text { coiled hair with } \\
\text { tapered end } \\
\text { resembling a pig's tail }\end{array}$ & $\begin{array}{l}\text { - A circular hair } \\
\text { with a thicker } \\
\text { extremity } \\
\text { comparing to } \\
\text { pigtail hair } \\
\text { - May } \\
\text { occasionally have } \\
\text { a hook-like } \\
\text { appearance }\end{array}$ & $\begin{array}{l}\text { - A hair winding many } \\
\text { times around itself } \\
\text { - Perifollicular hemorrhage } \\
\text { (ascorbic acid deficiency) }\end{array}$ \\
\hline Distribution & $\begin{array}{l}\text { Abdomen, back, } \\
\text { trunk, and thighs }\end{array}$ & $\begin{array}{l}\text { Extensor extremities, back, } \\
\text { shoulders, and buttocks }\end{array}$ & Scalp & Scalp & $\begin{array}{l}\text { - Scalp (tinea capitis) } \\
\text { - Trunk and/or extremities } \\
\text { (ascorbic acid deficiency) }\end{array}$ \\
\hline $\begin{array}{l}\text { Dermoscopic } \\
\text { features }\end{array}$ & $\begin{array}{l}\text { A small diameter } \\
\text { hair shaft with } \\
\text { a perfectly circular } \\
\text { arrangement under } \\
\text { a translucent layer of } \\
\text { stratum corneum }\end{array}$ & $\begin{array}{l}\text { An irregularly twisted hair } \\
\text { into a hyperkeratotic } \\
\text { papule, peripilar cast }\end{array}$ & $\begin{array}{l}\text { A short, regularly } \\
\text { coiled oval or circular } \\
\text { hair with a tapered } \\
\text { end mimicking a pig's } \\
\text { tail representing the } \\
\text { rapidly growing hair }\end{array}$ & $\begin{array}{l}\text { An irregular oval } \\
\text { hair with a jagged } \\
\text { end }\end{array}$ & $\begin{array}{l}\text { - A hair with multiple } \\
\text { twists and coils forming } \\
\text { a corkscrew-like structure } \\
\text { - May be found trapped in } \\
\text { keratinaceous debris in } \\
\text { hair follicle together with } \\
\text { surrounding non- } \\
\text { blanchable perifollicular } \\
\text { hemorrhage in scurvy } \\
\text { patients }\end{array}$ \\
\hline Histopathology & $\begin{array}{l}\text {-"River bed" dilated } \\
\text { infundibular part of } \\
\text { the hair follicle } \\
\text {-Entrapped hair shaft } \\
\text {-No perifollicular } \\
\text { inflammation } \\
\text {-No tapering of hair } \\
\text { shaft diameter }\end{array}$ & $\begin{array}{l}\text {-Follicular hyperkeratosis } \\
\text {-Perifollicular inflammation }\end{array}$ & - & - & - \\
\hline $\begin{array}{l}\text { Associated } \\
\text { conditions }\end{array}$ & - None & $\begin{array}{l}\text {-Mechanical trauma } \\
\text {-Corticosteroids, } \\
\text { cyclosporine therapy } \\
\text {-Keratosis pilaris, xerosis, } \\
\text { neurodermatitis, } \\
\text { palmoplantar keratoderma, } \\
\text { lupus erythematosus, } \\
\text { alopecia areata, and } \\
\text { hypertrichosis }\end{array}$ & $\begin{array}{l}\text {-Repilation after acute } \\
\text { diffuse hair loss in } \\
\text { chemotherapy- } \\
\text { induced alopecia and } \\
\text { alopecia areata } \\
\text {-Telogen effluvium } \\
\text {-Trichotillomania } \\
\text {-Tinea capitis } \\
\text {-Syphilitic alopecia } \\
\text {-Triangular alopecia } \\
\text {-Hair-bearing margin } \\
\text { of cicatricial alopecia }\end{array}$ & $\begin{array}{l}\text {-Trichotillomania } \\
\text {-Traction } \\
\text { alopecia } \\
\text {-Healthy } \\
\text { individuals } \\
\text { resulting from } \\
\text { hair pulling } \\
\text { during the } \\
\text { hairstyling } \\
\text { process }\end{array}$ & $\begin{array}{l}\text {-Tinea capitis } \\
\text {-Ascorbic acid deficiency }\end{array}$ \\
\hline
\end{tabular}


Acquired ichthyosis is a nonhereditary cutaneous disease manifesting in adulthood as dry, rough skin with prominent scales. ${ }^{18}$ It commonly occurs on the trunk and extremities, especially on the extensor surfaces. ${ }^{18}$ The condition is associated with multiple diseases, eg, sarcoidosis, systemic lupus erythematosus, Hodgkin's and nonHodgkin's lymphoma, leiomyosarcoma, Kaposi's sarcoma, cutaneous T-cell lymphoma, and multiple myeloma. ${ }^{18-24}$ None of the medications used by our patient have been reported to cause acquired ichthyosis. ${ }^{2,3}$ Therefore, the etiology of the acquired ichthyosis in our patient is most likely multiple myeloma. In our case, the circle hairs may have occurred as a direct effect of multiple myeloma interfering with body-hair formation, resulting in thin and weak hair shafts. ${ }^{25}$ Consequently, acquired ichthyosis may impede the penetration of hairs through the skin surface, entrapping them and causing them to grow in a circular pattern.

There is no specific treatment for circle hairs, and reassurance that it is not a harmful condition is sufficient. ${ }^{1}$ We prescribed a topical humectant and keratolytic agent to moisten the skin and lessen the hair entrapment, which resulted in clinical improvement.

\section{Conclusion}

We report a case of co-occurrence of circle hairs and acquired ichthyosis in an older patient with underlying multiple myeloma. We also propose a possible mechanism of circle hairs and acquired ichthyosis occurring secondary to multiple myeloma. Circle hairs have the distinct feature of a perfectly coiled arrangement without perifollicular inflammation; however, physicians may be unaware of this disease owing to its rarity. As the pathogenesis of the disease is unknown, further studies are warranted.

\section{Ethics Approval and Consent to Participate}

This article was performed in accordance with the principles of Declaration of Helsinki. Ethical review and approval was not required to publish the case details in accordance with the local legislation and institutional requirements. Written informed consent was obtained from the patient for publication of this case report and any accompanying images as per our standard institutional rules.

\section{Disclosure}

The authors report no conflicts of interest in this work.

\section{References}

1. Contreras-Ruiz J, Duran-McKinster C, Tamayo-Sanchez L, OrozcoCovarrubias L, Ruiz-Maldonado R. Circle hairs: a clinical curiosity. $J$ Eur Acad Dermatol Venereol. 2000;14(6):495-497. doi:10.1046/ j.1468-3083.2000.00163.x

2. Lacarrubba F, Misciali C, Gibilisco R, Micali G. Circle hairs: clinical, trichoscopic and histopathologic findings. Int J Trichology. 2013;5 (4):211-213. doi:10.4103/0974-7753.130415

3. Lyakhovitsky A, Drousiotis T, Landov H, Baum S, Barzilai A. Circle hairs in a cardiac transplant patient. $J$ Eur Acad Dermatol Venereol. 2020;34(9):e472-e474. doi:10.1111/jdv.16381

4. Smith JB, Hogan DJ. Circle hairs are not rolled hairs. J Am Acad Dermatol. 1996;35(4):634-635. doi:10.1016/s0190-9622(96)90695-7

5. Leerunyakul K, Suchonwanit P. Asian hair: a review of structures, properties, and distinctive disorders. Clin Cosmet Investig Dermatol. 2020;13:309-318. doi:10.2147/ccid.S247390

6. Suchonwanit P, Rojhirunsakool S, Khunkhet S. A randomized, investigator-blinded, controlled, split-scalp study of the efficacy and safety of a 1550-nm fractional erbium-glass laser, used in combination with topical $5 \%$ minoxidil versus $5 \%$ minoxidil alone, for the treatment of androgenetic alopecia. Lasers Med Sci. 2019;34 (9):1857-1864. doi:10.1007/s10103-019-02783-8

7. Seçkin D, Güleç TO, Haberal M. Higher incidence of rolled hairs in renal transplant recipients: a possible complication of corticosteroid and cyclosporine therapy. Acta Derm Venereol. 1998;78(5):384. doi:10.1080/000155598443150

8. Iamsumang W, Leerunyakul K, Suchonwanit P. Finasteride and its potential for the treatment of female pattern hair loss: evidence to date. Drug Des Devel Ther. 2020;14:951-959. doi:10.2147/dddt. S240615

9. Ortonne JP, Juhlin L, El Baze P, Pautrat G. Familial rolled and spiral hairs with palmoplantar keratoderma. Acta Derm Venereol. 1985;65 (3):250-254.

10. Suchonwanit P, Iamsumang W, Rojhirunsakool S. Efficacy of topical combination of $0.25 \%$ finasteride and $3 \%$ minoxidil versus $3 \%$ minoxidil solution in female pattern hair loss: a Randomized, Double-Blind, Controlled Study. Am J Clin Dermatol. 2019;20 (1):147-153. doi:10.1007/s40257-018-0387-0

11. Waśkiel A, Rakowska A, Sikora M, Olszewska M, Rudnicka L. Trichoscopy of alopecia areata: an update. J Dermatol. 2018;45 (6):692-700. doi:10.1111/1346-8138.14283

12. Esteves ALV, Serafini NB, Lemes LR, Melo DF. Circular hairs: nomenclature and meanings. An Bras Dermatol. 2017;92 (6):874-876. doi:10.1590/abd1806-4841.20176487

13. Sriphojanart T, Khunkhet S, Suchonwanit P. A retrospective comparative study of the efficacy and safety of two regimens of diphenylcyclopropenone in the treatment of recalcitrant alopecia areata. Dermatol Rep. 2017;9(2):7399. doi:10.4081/dr.2017.7399

14. Rudnicka L, Rakowska A, Kerzeja M, Olszewska M. Hair shafts in trichoscopy: clues for diagnosis of hair and scalp diseases. Dermatol Clin. 2013;31(4):695-708, x. doi:10.1016/j.det.2013.06.007

15. Suchonwanit P, Udompanich S, Thadanipon K, Chanprapaph K. Trichoscopic signs in systemic lupus erythematosus: a comparative study with 109 patients and 305 healthy controls. J Eur Acad Dermatol Venereol. 2019;33(4):774-780. doi:10.1111/jdv.15421

16. Walters RW, Grichnik JM. Follicular hyperkeratosis, hemorrhage, and corkscrew hair. Arch Dermatol. 2006;142(5):658. doi:10.1001/ archderm.142.5.658

17. Hughes R, Chiaverini C, Bahadoran P, Lacour JP. Corkscrew hair: a new dermoscopic sign for diagnosis of tinea capitis in black children. Arch Dermatol. 2011;147(3):355-356. doi:10.1001/ archdermatol.2011.31

18. Patel N, Spencer LA, English JC 3rd, Zirwas MJ. Acquired ichthyosis. J Am Acad Dermatol. 2006;55(4):647-656. doi:10.1016/ j.jaad.2006.04.047 
19. Suchonwanit P, Hector CE, Bin Saif GA, McMichael AJ. Factors affecting the severity of central centrifugal cicatricial alopecia. Int J Dermatol. 2016;55(6):e338-e343. doi:10.1111/ijd.13061

20. Chanprapaph K, Udompanich S, Visessiri Y, Ngamjanyaporn P, Suchonwanit P. Nonscarring alopecia in systemic lupus erythematosus: a cross-sectional study with trichoscopic, histopathologic, and immunopathologic analyses. $J$ Am Acad Dermatol. 2019;81 (6):1319-1329. doi:10.1016/j.jaad.2019.05.053

21. Suchonwanit P, Triamchaisri S, Wittayakornrerk S, Rattanakaemakorn P. Leprosy reaction in Thai population: a 20-year Retrospective Study. Dermatol Res Pract. 2015;2015:253154. doi:10.1155/2015/253154

22. Chanprapaph K, Mahasaksiri T, Kositkuljorn C, Leerunyakul K, Suchonwanit P. Prevalence and risk factors associated with the occurrence of autoimmune diseases in patients with alopecia areata. J Inflamm Res. 2021;14:4881-4891. doi:10.2147/jir.S331579
23. Aram H. Acquired ichthyosis and related conditions. Int $J$ Dermatol. 1984;23(7):458-461. doi:10.1111/ijd.1984.23.7.458

24. Chanprapaph K, Leerunyakul K, Niparuck P, Rutnin S. A clinical and histological comparison between acute cutaneous graft-versus-host disease and other maculopapular eruptions following hematopoietic stem cell transplantation: a retrospective cohort. Int $J$ Dermatol. 2020;60(1):60-69. doi:10.1111/ijd.15186

25. Suchonwanit P, McMichael AJ. Alopecia in association with malignancy: a review. Am J Clin Dermatol. 2018;19(6):853-865. doi:10.1007/s40257-018-0378-1

\section{Publish your work in this journal}

Clinical, Cosmetic and Investigational Dermatology is an international, peer-reviewed, open access, online journal that focuses on the latest clinical and experimental research in all aspects of skin disease and cosmetic interventions. This journal is indexed on CAS.
The manuscript management system is completely online and includes a very quick and fair peer-review system, which is all easy to use. Visit http://www.dovepress.com/testimonials.php to read real quotes from published authors. 